\title{
Engineering Education addressing Professional Challenges
}

\author{
Clara Viegas \\ Department of Physics \\ ISEP/P.Porto \\ Porto, Portugal \\ mcm@isep.ipp.pt
}

\author{
Arcelina Marques \\ Department of Physics \\ ISEP/P.Porto \\ Porto, Portugal \\ mmr@isep.ipp.pt
}

\author{
Gustavo R. Alves \\ Department of Electrotechnics \\ ISEP/P.Porto \\ Porto, Portugal \\ gca@isep.ipp.pt
}

\begin{abstract}
Engineering profession is very demanding because of the different competences young graduates need to master. The exponential growth in technology, even though very beneficial to all, tends to worsen their needs of expertise, having to endlessly update themselves. Engineering education has been addressing these issues, hoping to contribute to better teaching practices more aligned with engineering professional world. Students must develop the necessary competences from the beginning of their education and engage into actively learning the subjects. Three aspects of this problematic are presented in this special session: educational experiences, students' learning and professional challenges.
\end{abstract}

\section{CCS CONCEPTS}

- Applied computing - Physical sciences and engineering - education

\section{KEYWORDS}

Didactics; Teaching methodologies; Competence Development; Engineering Education; Young Engineers Challenges; Laboratory Experimentation

\section{ACM Reference format:}

Clara Viegas, Arcelina Marques and Gustavo R. Alves. 2019. Engineering Education addressing Professional Challenges. In Proceedings of the Seventh International Conference on Technological Ecosystems for Enhancing Multiculturality (TEEM 2019) (León, Spain, October 16-18, 2019), ACM, New York, NY, USA, 3 pages. https://doi.org/10.1145/3362789.3362942

\section{Introduction}

Some students we currently teach might be able to live through 3 centuries! Doing the math: they were born in the end of the $20^{\text {th }}$ century, study in the $21^{\text {st }}$ and some of them might get to see the

Permission to make digital or hard copies of all or part of this work for personal or classroom use is granted without fee provided that copies are not made or distributed for profit or commercial advantage and that copies bear this notice and the full citation on the first page. Copyrights for components of this work owned by others than ACM must be honored. Abstracting with credit is permitted. To copy otherwise, or republish, to post on servers or to redistribute to lists, requires prior specific permission and/or a fee. Request permissions from Permissions@acm.org.

TEEM'19, October 16-18, 2019, León, Spain

(C) 2019 Association for Computing Machinery.

ACM ISBN 978-1-4503-7191-9/19/10...\$15.00

https://doi.org/10.1145/3362789.3362942 $22^{\text {nd }}$ century! This overwhelming fact alone acknowledges we are living a unique era. Parallel to this fact, this generation already grew up during a leap in technology which undoubtedly speed up in future years [1]. The challenges they will be facing have nothing to do with the challenges of previous generations [2, 3]. Establishing a similarity with student's examinations: who are the ones most likely to succeed? Teachers often take critiques their exams are too difficult and different from what was practiced. For one reason or another, students are partially right. Hopefully, an exam must present students with some challenge (not the exact same problems with different inputs they already overcome). So, exams will always be difficult! Expectantly, students will be able to crack those challenges using the developed competences [4]. In the perfect world, all students will! Often that does not happen. On the other hand, sometimes teachers tend to forget minor difficulties they struggled when they were studying those subjects for the first time. Due to their scientific maturity, all is so clear and easy, they genuinely have trouble figuring why students fail [5]. Adding to these factors, often some students are more focused in passing than in learning. Sometimes they tend to develop strategies that allow them to overcome one small barrier without overthrown it. Unfortunately, that barrier will be on top of the next one. Soon the barrier becomes too big. With time, perseverance and scientific maturity, all can be accomplished [5]. The point is, time is something these upcoming generations lack. So, as in their academic life, future engineers need to be prepared to daily overcome themselves and face technological updates at a race beyond our imagination $[1,2,3]$. The ones more equipped to survive will probably be the ones who scientifically grew up developing competences while learning the subjects $[4,5]$. The question is: how can we help them getting engaged and better prepared to accomplish that?

\section{Engineering Education addressing Professional Challenges}

Engineering education has been addressing important subjects and calling attention to particular aspects teachers and universities must be aware regarding the demands future graduate students will have to endure [6, 7]. Regarding professional challenges, some directives concerning students' competences have been disseminated over the last years $[8,9]$. Their expertise must rely not only on their knowledge and competence to deal with new situations but also on their social and professional skills such as team workers, leadership, 
management, creativity, ethics, communication, among others [2, $10,11,12]$. Taking into account these problematics, some of the proposed topics regarding this track were related to the following topics:

- Project work in engineering education

- PBL engineering experiences

- Learning gains from contacts with engineering profession

- Improving engineering professional, social and/or scientific competences

- Engineering graduate students' competences versus companies' professional needs

- Long term vision about engineering education

- Capstone projects - final year projects

- Cornerstone projects - first year projects

- Emerging technologies in teaching

- Merging academia and professional practices

- Multicultural aspects of engineering education

\section{Contributions}

Most of the contributions to this special track at TEEM'19 versed teachers' perspectives, curricula design, strategies or educational experiences descriptions.

Even though focusing on didactics, the majority made a strong association with the final purpose, such being: development of students' competences, enhance learning or students' engagement.

Some contributions made clear the importance of professional practices, adding students making the transition to the working environment.

The presented works addressed three vectors: educational experiences, students' learning and professional challenges. Most of them tackle the link between them.

\subsection{Educational Experiences}

Every work presented shows some insight about an educational experience. This is understandable since all papers were written by higher education teachers from universities and polytechnics. Even though these works came from different parts of the world, such as Mexico, Norway, Portugal and Spain, they address similar concerns. Different perspectives were presented:

1. Reflecting upon teachers' practice

2. Designing particular aspects of course curricula: project work, laboratory implementations, remote labs, simulations usage and other computer-based activities

3. Implementing computer solutions to aid teachers managing course curricula

4. Reporting different teaching strategies

5. Making liaisons to engineering professional activities

Different efforts towards good practices among teachers may be found in these works. From (i) the designing of an activity and the description of its implementation, to (ii) the report of the actual practice and perceived results, it embodies a vast difference. The works which report both aspects can give the readers a closer approach of the reality, since what teachers plan to do, not always is what they end up doing due to several constrains [13]. Although not all the presented works portray the former aspect, they represent works in progress which are still worth telling experiences that can be inspiring to others.

\subsection{Students' Learning}

All the presented papers reflect the importance of not only being concern about the way the teaching may occur, but also about ways students' learning may be enhanced. This acknowledge the significance this element plays in teachers minds. There are no longer teachers whose only worry is to run the syllabus down. The constant worry of what students must develop in order to successfully progress in their studies and in their future profession was here expressed through:

1. Experimental competences development

2. Multidisciplinary competences development

3. Social competences development (in particular communication and team work)

4. Professional techniques development.

\subsection{Professional Challenges}

Some works also reflected the already expressed necessity of allowing students to contact with professional environments and demands. There was also a call for attention at particular areas such as metrology or the writing of a report, which may often be neglected but which plays a crucial role in any engineer profession. Multicultural experiences are also mentioned and represents a good example of showing students how to deal with a global professional world. These works represent important contributions that particularly highlight:

1. Professional environments simulations

2. First contacts in loco with the engineer profession

3. Transversal engineering domains expertise.

\section{Final Remarks}

The awareness of the importance of Engineering Education is patent in the conscience of today's higher educators. Most of the concerns are shared by teachers, students and professionals. The growing challenges engineering profession faces leads to continually pursue more effective practices. The majority of works presented addressed the linkage between teachers' didactical activities, students learning issues and professional challenges and demands:

First, the awareness of the importance of designing activities that enhance students learning and engagement. Tasks more devoted to developing experimental competences, project work, team work, social skills or computer-interactive environments were some of the highlighted aspects.

Second the acknowledge of the concern regarding students learning, pursuing more successful practices which can develop more prepared professionals. 
Finally, addressing specific activities towards the enhancement of professional techniques or the ability of performing activities close to professional environments.

\section{ACKNOWLEDGMENTS}

The chairs of this track session would like to thank the members of its Scientific Committee and all contributing authors for their efforts in enhancing the discussion upon this thematic. The authors would also like to acknowledge the financial support provided by the Foundation for Science and Technology Project, FCT UID/EQU/04730/2013.

\section{REFERENCES}

[1] Maxine Driscoll, Education in the $21^{\text {st }}$ Century, Think Strategic, https://thinkstrategicforschools.com/education-21st-century/. [retrieved in 2019]

[2] B. Johansen (2012). Leaders Make the Future, B. Publishers, Ed.

[3] L. Morell (2015). Disrupting Engineering Education to Better Address Societal Needs. Proceedings of 2015 International Conference on Interactive Collaborative Learning (ICL), Florence, Italy.

[4] E. Crawley, J. Malmqvist, S. Ostlund and D. Brodeur (2007). Rethinking Engineering Education - The CDIO Approach. Springer, NY, USA.

[5] R. Felder, D. Woods, Stice, E. e A. Rugarcia (2000). The Future of Engineering Education II. Teaching Methods that Work," Chem. Engr. Education, 34(1), 2639
[6] M. Borrego and J. Bernhard (2011). The emergence of engineering education research as an internationally connected field of inquiry. Journal of Engineering Education, 100 (1), 14-47.

[7] Martin Grimheden (2007). From Capstone Courses to Cornerstone Projects: Transferring Experiences from Design Engineering Final Year Students to First Year Students. Royal Institute of Technology, ASEE, AC 2007-1582.

[8] A. Karabulut-Ilgu, N. J. Cherrez and C. T. Jaharen (2018). A systematic reviewe of research on the flipped learning method in engineering education. British fournal of Educational Technology, 49(3), 398-411.

[9] A. Sánchez-Martí, M. S. Puig., A. Ruiz-Bueno and R. A. Regós (2018). Implementation and assessment of an experiment in reflective thinking to enrich higher education students' learning through mediated narratives. Thinking Skills and Creativity, 29, 12-22.

[10] C. Viegas, A. Marques and G. Alves (2018). Engineering Education and Technological / Professional Learning. In Proceedings of the Sixth International Conference on Technological Ecosystems for Enhancing Multiculturality (TEEM 2018), Salamanca, Spain.

[11] C. Viegas, A. Marques and G. Alves (2017). 21 $1^{\text {st }}$ Century Challenges in Engineering and Technological Learning. In Proceedings of the Fifth International Conference on Technological Ecosystems for Enhancing Multiculturality (TEEM 2017), Cadiz, Spain.

[12] A. Y. Huang-Saad, C. S. Morton and J. C. Libarkin (2018). Entrepreneurship Assessment in Higher Education: A Research Review for Engineering Education Researchers. Journal of Engineering Education, 107(2), 263-290.

[13] C.Viegas (2017). The Development of Competences in Engineering Students. J.B. Lopes, J. P. Cravino, E. S. Cruz and A. Barbot (Eds) Teaching Science: Contibutions of Research for Planning, Practice and Professional Development. NOVA Science Publishers, New York, 189-208. 